\title{
SECUENCIA Y TEMPORALIDAD EN “DESHORAS" DE JULIO CORTÁZAR
}

Marisa Abdala

Julio Cortázar es uno de los escritores latinoamericanos que, junto con Carpentıer, Fuentes y Vargas Llosa, han rechazado la narración lineal característica del siglo XIX en favor de narraciones cuya estructura refleje mejor la concurrencia de distintos planos espacio-temporales. En algunas de sus novelas, como en Rayuela, Cortázar destruye la secuencia utilizando la yuxtaposición y el collage. Con frecuencia se mezclan diferentes planos, como en su cuento "Continuidad de los parques", en donde aparece un personaje lector de una novela que, a medida que la narración avanza, se transforma en el personaje central de la misma novela que lee; relación que a la vez nos involucra a nosotros como lectores-personajes del cuento que leemos. En Cortázar, el tema del escritor frente a su obra o el narrador frente al texto es un tema recurrente. En el Libro de Manuel "el que te dije" es el personaje que, además de ser el alter ego de varios de los personajes en la novela, encarna las preocupaciones del escritor ante el acto de narrar. Es así como el Libro de Manuel pasa a ser una novela que se concentra en la preocupación del escritor por conciliar la literatura y la política dentro de la narración. Paralelamente a la narración de la historia, tenemos la conciencia del narrador dejando entrever el proceso mismo de estructuración de la novela. "Deshoras" es un ejemplo reciente de este procedimiento narrativo en Cortázar.

En "Deshoras" la narración oscila entre dos niveles: el del relato y el de la narración. El narrador en “Deshoras", como el Marcel de Proust, se remonta a sus años de adolescencia para relatarnos una etapa de su vida en la que Sara, la hermana de Doro, es el eje conductor del relato. Por un lado, la narración se estructura a partir de la evocación de este tiempo pasado y por otro, a partir de la interacción de dos líneas espacio-temporales: la del narrador frente al acto de narrar, la del narrador frente a su relato. A continuación veremos de qué forma se conjugan estos dos niveles: el del relato y el de la narración.

Emplearemos el método de análisis descrito por Gérard Genette en Narrative Discourse. Nos referiremos especialmente a las categorías de orden y frecuencia, ya 
que éstas serán de gran utilidad para ver ciertos aspectos relacionados con el manejo del tiempo y la mezcla de diferentes líneas espacio-temporales dentro de la narración. La categoría de orden determina las figuras temporales que se crean a partir de la no-coincidencia entre la secuencia diegética ${ }^{1}$ y la secuencia narrativa. A estas figuras Genette las llama anacronías y las divide en analepsias, prolepsias y silepsias. ${ }^{2}$ La frecuencia establece las relaciones de coincidencia entre el número de veces que se narra un suceso y el número de veces que sucede en la historia. A estas figuras Genette las llama "narración iterativa", "narración singulativa" y "narración repetitiva". ${ }^{3}$ La teoría de la narración de Genette es compleja y sofisticada en su terminología. Sin embargo, es de gran utilidad cuando la complejidad de la estructura narrativa, como en el caso de Cortázar, requiere de un marco referencial que la cubra. La utilización de una teoría tan elaborada en la interpretación de la obra conlleva el riesgo de que se subordine la obra a la teoría en lugar de que ésta se utilice para iluminar a la primera. Por ello he elegido sólo aquellos aspectos que considero de más relevancia en el análisis de la estructura narrativa en "Deshoras".

"Deshoras" comienza con el narrador haciendo referencia a su posición como narrador y a las razones que lo llevan a escribir sus recuerdos de la infancia. Ya desde este momento la narración se plantea como el medio para reflejar la existencia simultánea de diferentes tiempos y espacios en la memoria del que narra: “...me ocurría preguntarme a veces si esos recuerdos de la infancia merecían ser escritos, si no nacían de la ingenua tendencia a creer que las cosas habían sido más de veras cuando las ponía en palabras para fijarlas a mi manera..." El tipo de narración autobiográfica que Cortázar emplea en "Deshoras", a diferencia de las narraciones autobiográficas en primera persona, nos indica el momento preciso de transición entre el yo que narra y el yo narrado. Cuando la narración deja a un lado la reflexión sobre el acto de narrar y pasa al relato de aquellos días que inevitablemente surgen en la memoria junto con el recuerdo de Doro y Sara, el narrador deja de referirse a él mismo en primera persona para narrarse en el pasado utilizando la tercera persona. Este cambio de primera a tercera persona crea un efecto que disloca al narrador de su yo narrado; efecto que, como veremos más adelante, se disuelve a medida que avanza la narración. Genette nos dice cuando se refiere al código de focalización en las narraciones autobiográficas: "...the autobiographical type of narrator... is - by the very facto of his oneness with the heromore naturally authorized to speak in his own name than is the narrator of the third

1 Aquí utilizo el término diegético en sentido genettiano para definir el universo espaciotemporal creado por el relato.

2 Analepsia: cuando se narra después lo que sucedió antes. Prolepsia: cuando se narra antes lo que sucede después. Silepsia: agrupamientos no cronológicos como los espaciales o temáticos.

${ }^{3}$ Narración singulativa: cuando se narra una vez lo que sucede una vez Narración repetitiva: cuando se narra $n$ veces lo que pasa una vez. Narración iterativa: cuando se narra una vez lo que sucede $n$ veces.

‘ Julio Cortázar, "Deshoras", en Deshoras, México, Nueva Imagen, 1983, p. 101. Las referencias posteriores a esta obra aparecen entre paréntesis en el texto. 
Tomaremos como tiempo central de la narración el tiempo con el que ésta inicia: el narrador preguntándose sobre las razones que lo llevan a escribir sus recuerdos. Poco después de iniciarse el relato se da la analepsia que nos remonta a aquellos person narrative". Genette expone las constantes transgresiones al código de focalización en la Recherche, precisamente por la dificultad que surge al tratar de distinguir entre narrador y héroe en una narración autobiográfica en primera persona. En "Deshoras" la focalización también es variable, pero a diferencia de la Recherche, en donde el cambio de focalización no es tan obvio, el cambio de primera a tercera persona nos indica el momento preciso en que se pasa de la conciencia del narrador a la conciencia del personaje.

dias en Bánfield, con Doro y Sara, para continuar con el traslado de Aníbal a Buenos Aires; se acerca, a medida que la narración avanza, al momento inicial del relato. Pero en este fluir del presente al pasado de pronto interviene la fantasía del narrador: su encuentro con Sara en Buenos Aires, sus conversaciones, la posibilidad de vivir ese amor idealizado. La analepsia se traslapa de esta forma con el presente del narrador. El relato, hasta el momento en que el narrador recuerda un sueño reciente con Sara, es una evocación, un hurgar en la memoria de aquellos días. Pero a partir del momento en que recuerda el sueño, el relato continúa con su fantasía. La narrración no da señal alguna de este paso de la memoria hacia la fantasia sino hasta el final, cuando el acto narrativo, como al inicio de la narración, vuelve a ser acción:

Había querido seguir y que también las palabras aceptaran seguir adelante hasta llegar al hoy nuestro de cada día... pero entonces me había acordado del sueño de la noche anterior... y no había podido quedarme en este presente en el que una vez más saldría por la tarde del estudio y me iría a beber una cerveza al café de la esquina, las palabras habían vuelto a llenarse de vida y aunque mentían, aunque nada era cierto, había seguido escribiéndolas porque nombraban a Sara (p. 117).

No es sino hasta este momento, en el que la narración vuelve sobre el acto narrativo, cuando descubrimos que el encuentro con Sara no forma parte del recuerdo como el resto del relato, sino que ha sido inventado por el narrador. El narrador dice que las palabras "habían corrido cabalgando la realidad" hasta el momento en que el relato empieza a hacerse cotidiano, sin recuerdos ni sueños. La fantasía del reencuentro con Sara es un escape de esta cotidianidad, un deseo de prolongar, a través de las palabras, esos momentos que aparecen cargados de una vitalidad ahora inexistente.

La analepsia que da lugar al relato de aquellos años en Bánfield, pasando por Buenos Aires y por la fantasía del reencuentro con Sara, concluye después del momento en que la narración se interrumpio para dar lugar a esta figura de orden. ${ }^{6}$

5 Gérard Genette, Narrative Discourse, New York, Cornell University Press, 1981, p. 198.

- A este tipo de analepsias Genette las llama "analepsias mixtas": aquéllas cuyo alcance abarca un período que empieza antes de la línea central del relato (tiempo de la narración) y termina después. 
El tiempo de la narración, anterior a la anacronía, Genette lo llama el "presente" de la narración. La analepsia empieza con el relato de Aníbal y Doro en Bánfield y narra lo que va sucediendo hacia el "presente" de la narración. Sólo que antes de llegar a este "presente", cuando aún falta un lapso de tiempo por narrar, la fantasía del narrador sustituye el relato cotidiano de las jornadas en la escuela de ingeniería. La analepsia avanza de un tiempo rememorado hacia un tiempo inventado. La fantasía en realidad sustituye a una elipsis, es decir, la omisión de una parte del relato. Una vez que el narrador vuelve sobre sus palabras, para hacernos partícipes del engaño, nos narra, a través de una analepsia completiva, la sección del tiempo que había omitido. Esta segunda analepsia se nos da en forma de resumen y aunque aún queda una parte sin narrar, es fácil suponer que por fin el narrador se casó con Felisa, terminó sus estudios y tuvo dos hijos.

Dentro de esta gran analepsia del pasado rememorado surgen una serie de subestructuras que se constituyen a partir de las relaciones de frecuencia entre la narración y la diégesis y que contribuyen a definir la temporalidad de la narración. La analepsia que discutimos en las páginas anteriores se construye a partir de una serie de relatos que funcionan como piezas de un rompecabezas en la memoria del narrador. Las primeras series o secciones del relato, como las tres primeras secciones de la Recherche, son esencialmente iterativas. A medida que la narración avanza, que se acerca al "presente" de la narración, las escenas singulativas empiezan a multiplicarse hasta llegar a transformarse en narración singulativa con la fantasía del encuentro con Sara. Más adelante veremos cómo una serie iterativa puede contener escenas singulativas o a la inversa, cómo una narración singulativa puede generar la narración en el iterativo.

Aunque el relato que se encierra dentro de esta analepsia sigue una cronología externa que describe los años en Bánfield y después el traslado a Buenos Aires, los agrupamientos de las series que forman el relato son silépticos ya que no siguen un orden cronológico riguroso, sino que están agrupados con base en ordenamientos espaciales, temporales o temáticos. El paso de una sección a otra aparece indicado en el texto por medio de los espacios en blanco entre una y otra. Empezaremos por ver las primeras dos series que integran el relato. En las dos el ordenamiento es temático: la primera es la descripción de Bánfield, la segunda gira en torno a la presencia de Sara en el mundo de Aníbal. Ambas secciones están narradas en el iterativo que, al igual que en francés, se caracteriza por el uso del pasado imperfecto. La primera de estas series empieza con la descripción de Bánfield. Aun cuando Bánfield, a diferencia del resto del relato, ha permanecido en el tiempo, el uso del imperfecto crea la sensación de que las calles y casas de Bánfield sólo existen en la conciencia del narrador con relación a esta etapa de su vida. La descripción de los faroles, las calles, el verano en Bánfield, es la descripción de Doro y Aníbal recorriendo esas calles, mirando los insectos dar vuelta en torno a los faroles, disfrutando de la libertad y el olor del verano en Bánfield. En la segunda serie iterativa, separada de la anterior por un espacio en blanco en el texto, el relato gira en torno a las imágenes que el narrador conserva de Sara: “A las cinco los llamaba para darles café con leche y bizcochos..." (p. 103). 
Dentro de estas series iterativas hay subseries. Por ejemplo, en la primera sección -Bánfield - tenemos la subserie "veranos" y al final de la segunda sección la subserié "inviernos". Dentro de estas subseries el iterativo aparece indicado por una sucesión de sustantivos e infinitivos y no como en el resto de la serie a través del uso del imperfecto:

Y el verano, siempre, el verano de las vacaciones, la libertad de los juegos, el tiempo sola mente de ellos, para ellos, sin horario ni campana para entrar a clase, el olor del verano en el aire caliente... (pp. 102-103).

O la subserie "inviernos":

... de los inviernos no tenía casi recuerdos, su casa se volvía un encierro gris y neblinoso donde sólo los libros contaban, la familia en sus cosas y las cosas fijas en sus huecos, las gallinas que él tenía que cuidar, las enfermedades con largas dietas y té y solamente a veces Doro... (p. 104).

Se acelera el ritmo de la narración y se crea la sensación de que las imágenes se agolpan en la memoria del narrador a una velocidad que el lenguaje no puede captar.

La siguiente sección gira en torno a un hecho singulativo: "la bronquitis de Anibal" tratado en forma iterativa. Aunque el episodio "bronquitis" es un hecho aislado, el uso del imperfecto indica que los hechos que se narran se repitieron varias veces en el transcurso de la enfermedad: Doro venía a visitar y preguntaba por Sara. Dentro de la serie bronquitis aparecen otras escenas singulativas como la descripción que empieza: “Antes de dormirse esa noche, Aníbal sintió que algo le subia a los ojos, que la almohada se le volvía Sara..."(p. 104). Esta escena no sólo describe un hecho aislado en el pasado, sino que también ejerce una función ilustrativa del iterativo, puesto que marca el inicio de una serie de noches en que Aníbal experimentaba la misma sensación. Más adelante, el relato de las noches antes de acostarse aparece narrado de nuevo en el iterativo, utilizando el "imperfecto" y no el "perfecto" como en esta primera escena singulativa. En la siguiente serie iterativa, cuyos límites diacrónicos los señala la determinación externa:7 "Era de nuevo el verano...", encontramos de nuevo la narración de las noches de Aníbal antes de acostarse: "Pero de noche era triste y a la vez tan hermoso... y el llanto volvía como un deseo de entrega, de ser Doro en las manos de Sara, de que el pelo de Sara le rozara la frente y su voz le dijera buenas noches, que Sara le subiera la sábana antes de irse" (p. 105). La narración repetitiva de la fantasía de Aníbal enfatiza el elemento obsesivo de su sentimiento por Sara. Sara había llegado a ocupar sus pensamientos, sus sueños, incluso sus conversaciones con Doro estaban cargadas de ella.

${ }^{7}$ Determinación externa es la información que define los límites diacrónicos de una serie. Por ejemplo: Empezaba el verano. 
La siguiente sección del relato, "El día del zanjón", es también una escena singulativa. La narración está en perfecto, pero al igual que en la serie "bronquitis", el relato de este suceso se abre para dar cabida a la narración iterativa: "Les gustaba sentarse al borde y fumar los cigarrillos que Doro hacía con chala de maíz..." (p. 107). Esta sección incluye la narración de otra escena singulativa: un buen día Doro y Aníbal resbalan en la zanja. Sara, al verlos, los manda a ducharse. Poco después entra al baño para ayudarlos a asearse y los ve desnudos, hecho que pone fin a las fantasías de Anibal con Sara. Más adelante esta escena se narra otra vez en el supuesto diálogo entre ellos, años después, en Buenos Aires. Durante este diálogo imaginado que Aníbal tiene con Sara, lo ya narrado se retoma para aparecer ahora en boca del personaje: “... me enamoré tanto de vos, me enamoré tanto y no te lo podía decir, vos venías de noche y me cuidabas..."(p. 115). Ahora el personaje dice todo lo que hubiera querido decir en aquel entonces, actúa lo que hubiera deseado actuar. La conversación entre los dos es apresurada, sin pausas, como queriendo terminar cuanto antes con aquel pasado que se interpone entre los dos y una forma de hacerlo es la vuelta al pasado con las palabras. Así al final de la conversación, cuando todo está dicho, ya no hay nada que le impida al narrador vivir la experiencia de un encuentro que de hecho nunca ocurre. La narración vueive entonces al presente y el narrador, frente al escritorio y con el vaso vacío, nos explica por qué mintió, por qué en determinado momento las palabras se alejaron del relato y se perdieron en la fantasía. El hubiera querido seguir, pero cuando la narración se acerca al presente utilitario opta por mentir, ya que de esta forma "las palabras habían vuelto a llenarse de vida"(p. 117). La narración responde de esta forma a las dudas que al inicio se plantea el narrador sobre las razones que lo llevan a escribir esos recuerdos de la infancia: “...me ocurría preguntarme a veces si esos recuerdos de la infancia merecían ser escritos, si no nacían de la ingenua tendencia a creer que las cosas habían sido más de veras cuando las ponía en palabras para fijarlas a mi manera..."(p. 101). Ahora sabemos que así es; que sí hay una tendencia por parte del narrador a utilizar las palabras para fijar las cosas a su manera. Como si las palabras tuvieran la posibilidad mágica de transformar la realidad pasada y hacerla más presente: “...la única manera de reunirme por fin con ella y decirle la verdad, ...irme con ella hacia una noche que las palabras irían llenando de sábanas y caricias..."(p. 117). Sabemos con el narrador que no es así. Sin embargo, también sabemos que el narrador volverá a las palabras para fijar las cosas a su manera; aun cuando a veces mientan y sólo mientras la "realidad presente" pueda ser interrumpida para dar lugar al recuerdo y la fantasía. El uso del imperfecto al principio del cuento: "...me ocurría preguntarme a veces si esos recuerdos de la infancia merecian ser escritos..."(p. 101), implica que como éste, ha habido otros relatos y probablemente seguirá habiéndolos a pesar de las limitaciones impuestas por la realidad misma.

Hemos visto, a través del análisis de las figuras de orden y frecuencia entre tiempo narrado y tiempo de la narración, cómo Cortázar construye una narración que llega a reflejar con bastante precisión la coexistencia en la conciencia del narrador de diferentes planos espacio-temporales: el recuerdo, la fantasía, el 
presente experimental. "Deshoras", como lo indica el título, es una narración que intenta reproducir fuera del tiempo lo ya vivido. El pasado se hace más presente, incluso se transforma a través de las palabras. La estructura narrativa y la convergencia de diferentes planos en la conciencia del narrador son una forma de responder a la pregunta que se hace éste al inicio. Sabemos, con el narrador, que la escritura es una forma de seguir creyendo que es posible cumplir con el deseo en lo imaginario y lograr esa tan deseada contigüidad entre el recuerdo, la fantasía y el presente experimental, aunque sólo sea por unos instantes. 